\title{
VIOLÊNCIA SISTÊMICA NA ORGANIZAÇÃO MILITAR DO IMPÉRIO E AS LUTAS DOS IMPERIAIS MARINHEIROS PELA CONQUISTA DE DIREITOS*
}

\author{
José Miguel Arias Neto**
}

\begin{abstract}
RESUMO
Procura-se demonstrar neste artigo que uma violência sistêmica caracterizava a organização militar no Brasil Império. A partir de um movimento das praças por direitos, foi possível detectar as características básicas daquela organização.
\end{abstract}

Palavras-chaves: violência, sistema militar, movimentos sociais.

\begin{abstract}
This article intends to show that the military organization in Empire of Brazil has been characterized by a systemic violence. We could understand the basics characteristics of those organization by the study of a Imperial Mariners movement for some rights.
\end{abstract}

Key-words: politics violence, military system, social movements.

* Este artigo constituiu parte da Tese de Doutorado: ARIAS NETO, J. M. Em busca da cidadania: praças da Armada Nacional, 1867-1910. São Paulo, 2001. Tese (Doutorado) - Universidade de São Paulo. A pesquisa foi financiada pela Capes. FFLCH-USP.

** Professor Adjunto da Universidade Estadual de Londrina. Doutor em História Social pela 


\section{Introdução}

Em janeiro de 1866, seis meses, portanto, após a batalha naval do Riachuelo, duzentos e sessenta e oito praças do corpo de imperiais marinheiros (incluindo o sargento ajudante do corpo, seis primeiros sargentos, seis forrieis, onze cabos de esquadra, dez marinheiros de segunda classe, cento e quatro de terceira e cento e trinta e um grumetes) dirigiram ao imperador D Pedro II e ao poder legislativo um requerimento no qual pediam

...submissamente a V. Majestade Imperial e aos augustos representantes da nação que [fosse] derrogado o decreto de 24 de outubro de 1854, na parte em que elevou a 20 anos o tempo de serviço, restabelecendo-se as disposições correspondentes do decreto de 5 de junho de 1845, tanto para as praças que forem de futuro alistadas, como para as que já pertencem ao corpo dos imperiais marinheiros. ${ }^{1}$

De acordo com o relatores da seção de Guerra e Marinha do Conselho de Estado, José Maria da Silva Paranhos e José Thomaz Nabuco de Araújo, os requerentes alegavam que os imperiais marinheiros estavam sujeitos a servir durante vinte anos,

...prazo de que não há exemplo em parte alguma do mundo; que vinte anos "é o máximo tempo de separação do mundo, da família e de torrão natal, a que a lei penal sujeita os grandes criminosos; que vinte anos, contados de dezoito a trinta anos de idade, são a melhor parte da vida do homem; e que, aplicados ao serviço

1 Transcrito na consulta da seção de Guerra e Marinha do Conselho de Estado de 11 de setembro de 1867, anexa ao Relatório do Ministério da Marinha (RMM), 1868, avisos e decretos, página 46. De agora em diante, será referenciada como "Consulta", seguida da indicação da página. É importante destacar que quando a seção analisou o documento, já iam avançadas as críticas à morosidade da guerra, instaurada depois do revés de Curupaiti, que tiveram por efeito acirrar a indisposição da Câmara e da imprensa com o gabinete Zacarias - já escarmentado por liberais históricos e conservadores que viram como uma imposição da coroa a enunciação da necessidade de emancipação do "elemento servil" na Fala do Trono de abertura da sessão da Assembléia Geral a 22 de maio de 1867 . Ver: NABUCO, J. Um estadista do Império. 5. ed. Rio de Janeiro: Topbooks, 1997; e HOLANDA, S. B. de. Do Império à República. In: HOLANDA, S. B. de. (Dir.). História geral da civilização brasileira: o Brasil monárquico. 4. ed. São Paulo: Difel, 1985. t. 2, v. 5. 
militar e de marinheiros, serviço tão arriscado e penoso, valem uma vida inteira, porquanto o indivíduo que depois disso se não acha de todo inutilizado, pouco pode prestar-se à sua família que muitas vezes tem esperado na miséria, esse largo espaço de tempo, pelo seu único arrimo; que tão longo prazo de serviço militar afugenta os voluntários, e deixa o corpo só com os recrutados e as praças procedentes das companhias de aprendizes marinheiros; que estes últimos, recebidos até com sete anos de idade, permanecem nas companhias respectivas até aos dezessete anos, prestando ali serviço de marinheiro, e que então passam para o corpo onde servem vinte anos, isto é, até a idade de trinta e sete anos; que em virtude do decreto $411 \mathrm{~A}$, de 5 de junho de 1845, já eram os imperiais marinheiros, por exceção, obrigados a servir 12 anos, e que este ônus posto que mais pesado do que o de qualquer outro servidor militar, era justificado pela dificuldade de fazer marinheiros; que o acréscimo de oito anos foi aceito e aplicado pela dificuldade de completar o corpo, e não o podia ser senão como medida provisória; que hoje porém, o corpo está completo, e com excesso que, segundo parece, irá sempre em aumento (Consulta, p. 46-47).

Essa petição apresenta problemas não explorados suficientemente pela Historiografia Brasileira que serão abordados neste artigo. Trata-se da questão da organização militar dos corpos inferiores da Armada Nacional, da violência sistêmica que caracteriza aquela organização e do modo de articulação das corporações militares com a estrutura social do Império. finalmente, dos movimentos de praças - praticamente desconhecidos pela historiografia - por conquista de direitos de cidadania.

\section{Da violência e dos direitos}

Várias questões chamam atenção no documento dos marinheiros. Em primeiro lugar, o documento em si, o ato dos marinheiros em reuniremse, deliberarem e elaborarem um requerimento ao governo imperial: neste sentido, o documento, antes da reivindicação que faz, é a expressão do exercício de um direito que, segundo parece, não era estranho aos seus signatários. A própria Constituição do Império garantia esse direito: 


\begin{abstract}
Art. $179 \ldots$
$\S 30$ - Todo cidadão poderá apresentar por escrito ao Poder Legislativo, e ao Executivo, reclamações, queixas, ou petições, e até expor qualquer infração da Constituição, requerendo perante a competente autoridade a efetiva responsabilidade dos infratores.
\end{abstract}

Pode-se imaginar que, talvez por se tratar de marinheiros, normalmente vindos das camadas mais humildes da população, a Constituição não fosse por eles conhecida. Porém, alguns indícios sugerem outras possibilidades. É sabido que havia uma certa prática por parte dos militares em apresentarem, nos dias turbulentos do Primeiro Reinado e da Regência, requerimentos e petições. ${ }^{2}$ Teria se mantido essa prática ao longo do regime imperial? Seria uma prática também entre os civis mais humildes ${ }^{3}$ A questão é de difícil resposta e somente novas pesquisas poderiam esclarecê-la. Contudo, um outro elemento pode contribuir para melhor situar esse requerimento. Antonio Paulino Limpo de Abreu, o visconde de Abaeté, na ocasião também fazia parte da seção de Guerra e Marinha do Conselho de Estado e, em seu parecer, dado em separado por razões que serão explicitadas no decorrer desta análise, observava que a petição dos marinheiros não era diferente de outras feitas ao governo "por oficiais e praças de corpos armados” (Consulta, p. 56). A própria solicitação, portanto, já expressava a consciência de direitos violados.

Esses elementos permitem supor que não se trataria de um caso extraordinário e, neste sentido, o requerimento torna-se mais significativo, pois poderia ser considerado como parte de uma série, o que demonstraria a existência de uma consciência social de direitos e permitiria uma melhor compreensão do exercício da cidadania no Brasil do século XIX.

2 A título de exemplo, é interessante lembrar da revolta do $26{ }^{\circ}$ Batalhão de Infantaria e do Corpo de Polícia do Rio de Janeiro a 12 de julho de 1831, à qual juntou-se a seguir quase toda a guarnição da Corte. Reunidas no Campo da Honra, as tropas dirigiram representação ao governo regencial, exigindo a supressão dos castigos corporais e fazendo o que Feijó, Ministro da Justiça, qualificou em ofício à Assembléia como "exigências extraordinárias". SOUZA, O. T. de. História dos fundadores do Império do Brasil: Bernardo Pereira de Vasconcelos. São Paulo: Edusp, 1988. p. 113-114.

3 Ao menos entre os grupos dominantes, ela parecia comum. São famosas, por exemplo, as representações feitas pelos paulistas ao príncipe regente em 1822 e a que Feijó dirigiu ao imperador em 1823. A primeira encontra-se em SOUZA, op. cit., p. 69-82; e a segunda em CALDEIRA, J. (Org.). Diogo Antonio Feijó. São Paulo: Editora 34, 1999. p. 60-65. 
Em segundo lugar, a imagem que os marinheiros faziam do serviço militar como castigo chocou profundamente, como se verá, os conselheiros de Sua Majestade. Finalmente, a ausência, nesses praças, de expectativas de vida e de futuro, visto considerarem que a melhor parte de sua vida seria "aplicada ao serviço militar e de marinheiro, serviço tão arriscado e penoso (....) porquanto o indivíduo que depois disso se não acha de todo inutilizado, pouco pode prestar-se à sua família (...)". Melhor destino não poderiam esperar os praças procedentes das companhias de aprendizes marinheiros que, ingressando nestas até com sete anos, "são transferidas para o corpo de imperiais marinheiros somente aos dezessete e, tendo de servir por vinte anos, permanecem de fato na Marinha por trinta anos".

O comandante geral do Corpo de Imperiais Marinheiros encaminhou o requerimento ao encarregado do quartel general da Marinha somente um ano depois, em janeiro de 1867. Vários motivos para tal demora podem ser aventados. Em primeiro lugar, como o requerimento foi redigido em nome de todo o corpo de marinheiros, é provável que os redatores tenham procurado recolher o maior número de assinaturas possível junto a seus companheiros. As dificuldades devem ter sido muitas, pois, de acordo com os dados disponíveis, verifica-se que no ano de 1865 , no início da guerra com o Paraguai, a força naval do Império era constituída de 45 navios armados ( 33 vapores e 12 veleiros) com seiscentos e nove oficiais e três mil seiscentos e vinte e sete praças, dos quais, compunham a flotilha do rio da Prata, 17 vapores e dois transportes de vela armados com 102 canhões e tripulados por dois mil trezentos e oitenta e quatro praças. Em outras palavras, durante o ano de 1866 deve ter sido extremamente difícil colher assinaturas para o requerimento, visto que $65 \%$ dos praças encontravam-se no teatro da guerra. Além disso, há de se considerar também a flotilha de Mato Grosso, composta por 6 vapores com cento e setenta e seis homens de guarnição, ${ }^{4}$ e que os demais praças encontravam-se dispersos pelos distritos navais do Império. Ainda entre os meses de janeiro e dezembro de 1866, mais 12 navios, tripulados por mil quinhentos e quarenta e nove praças foram reforçar a esquadra em operações na bacia do Prata. ${ }^{5}$

4 Fontes: RMM, 1864-1866.

5 No número total de praças, estão incluídos os voluntários e recrutados para as companhias de aprendizes, corpo de imperiais marinheiros e a marinhagem avulsa, contratada e recrutada. Segundo os relatórios do período, praticamente inexistiram Voluntários da Pátria na Marinha. 
Outro motivo que talvez justificasse a demora no encaminhamento da solicitação das praças poderia ser um provável desacordo do comandante do corpo em relação não apenas ao conteúdo do documento, mas à própria atitude de seus subordinados. Esta suposição, entretanto, não é pertinente. O capitão de mar e guerra, Elizário Antonio dos Santos, não apenas julgou o pedido digno de ser atendido, como também, em ofício de 22 de janeiro de 1867, acrescentou outras razões, elaboradas a partir de seu próprio ponto de vista, que reforçavam a petição:

\begin{abstract}
...visto ser verdade tudo quanto alegam os suplicantes, não só a respeito do estado de invalidez em que geralmente acabam de servir, na idade de quarenta a cinqüenta anos, porque em geral são recrutas, ou procedentes das companhias de aprendizes marinheiros, pois raros são os voluntários, a quem a aspereza da vida, reunida à severidade própria do serviço militar, afugenta, e só a estes é que mesmo o decreto dá menor e mais razoável tempo de dez a doze anos; como também, porque a tão crescido número de anos de serviço, e ainda por seu movimento por demais centralizado, se podem atribuir em parte as inúmeras deserções que os praças deste corpo cometem, pois é certo que já foi menor, quando em vigor as antigas disposições do decreto $\mathrm{n}^{\circ} 411 \mathrm{~A}$, da criação do corpo, que lhe dava somente doze anos de serviço obrigado (Consulta, p. 47).
\end{abstract}

Por sua vez, o encarregado do quartel general da Marinha, o chefe de divisão Antonio Leocádio do Couto, enviou ofício em 31 de janeiro do mesmo ano, consultando o conselho naval sobre a questão, e, embora reconhecendo que a legislação em vigor garantisse algumas vantagens às praças, sugeria que elas fossem optativas:

Encontro todo o fundamento nos argumentos dos peticionários. O período de vinte anos de serviço militar, de que não há exemplo em nação alguma, é em verdade excessivo; penoso e fatigante em um clima como o nosso, constitui uma vida para grande parte dos indivíduos que entraram para o corpo em idades já um tanto crescidas. Reconheço as vantagens que o novo regulamento garante às praças nos períodos de dez a vinte e seis anos, e no prazo final de vinte anos, mas perecia-me mais razoável que fossem elas facultativas, como acontecia com o anterior 
regulamento, o qual dava opção, proporcionando gratificações aos que continuassem no serviço depois de doze anos, e a reforma com meio soldo no fim de dezesseis anos (Consulta, p. 47).

A 5 de junho de 1867, o conselho naval, presidido pelo ministro Afonso Celso de Assis Figueiredo, em sua consulta 1125, apreciou a questão, e observou que os motivos apresentados pelos suplicantes, não só reconhecidos, mas fortalecidos pelo comandante do corpo e pelo encarregado do quartel general, eram impressionantes e que inclinaram-no a considerar justa a súplica endereçada, "tanto mais quanto tem ciência do horror com que em geral as praças encaram a idéia de servir por vinte anos, apesar de quantas vantagens lhes oferece o decreto 1465, de 25 de outubro de 1854". O conselho reconhecia que a legislação de 1854 revogava a anterior somente quanto ao tempo de serviço, que a solicitação dos marinheiros dizia respeito à restauração destes dispositivos e concluía - estando o corpo com número excedente ao seu efetivo completo - que o decreto de 1854 perdia sua razão de existir. Por outro lado, o conselho sugeria - frente às necessidades da presente guerra, período em que era previsível a abertura de vagas no corpo, fosse devido às mortes ou às "inutilizações" - o atendimento apenas parcial das solicitações apresentadas. Atento às observações do encarregado do quartel general, o conselho naval deu o seguinte parecer:

Que os $\S s 2^{\circ}$ e $3^{\circ}$ do art. $1^{\circ}$ do decreto ${ }^{\circ} 1465$, sejam substituídos pelos seguintes: $\S 2^{\circ}$ No fim de quatorze anos de serviço, a uma gratificação igual à metade do soldo; $\$ 3^{\circ}$ tendo completado dezesseis anos de serviço, a reforma correspondente à classe em que se acharem e, tendo completado vinte, a reforma com o soldo inteiro, também correspondente à classe em que se acharem (Consulta, p. 47).

A seção de Guerra e Marinha do Conselho de Estado julgou que não era conveniente efetuar nenhuma alteração na legislação em vigor, fosse baseada no requerimento das praças, nas observações dos comandantes militares ou na proposta do conselho naval. ${ }^{6}$ Os conselheiros de Sua Majestade

6 Houve um voto em separado do Visconde de Abaeté, que será comentado mais adiante. Como, no entanto, esse conselheiro foi vencido, a posição oficial da seção ficou sendo a que foi sustentada pelos conselheiros Nabuco e Paranhos. 
entenderam que "a estabilidade tão necessária nas organizações militares, e o alcance que pode ter a projetada inovação, aconselhariam que o governo imperial tornasse qualquer modificação do decreto de 1854 dependente de mais acurado estudo da matéria e de expressa autorização da assembléia geral" (Consulta, p. 50). Para justificar essa posição, a seção fez uma longa discussão acerca dos dispositivos que regulamentavam o tempo de serviço, bem como sobre as "vantagens" das praças do Corpo de Imperiais Marinheiros.

Os argumentos da seção de Guerra e Marinha partiram de uma comparação entre os dispositivos dos decretos 411-A e 1465.

\section{I - Decreto 411 A $05 / 06 / 1845^{7}$}

Art. 29. Os Imperiais Marinheiros que, como tais, servirem por espaço de seis anos, obterão, se quiserem licença, em tempo de paz para navegar em Navios Mercantes, por tempo de três anos, findos os quais deverão apresentar-se no Corpo, sob pena de serem considerados desertores. Os que completarem doze anos de serviço terão as suas baixas, exceto se quiserem continuar no mesmo serviço; e neste caso perceberão, além dos soldos competente às suas respectivas classes, uma gratificação de mais um Terço do mesmo soldo. Havendo completado dezesseis anos de serviço, terão direito à sua reforma, como uma pensão igual à metade do respectivo soldo.

Art. 30. Aqueles que assentarem praça voluntariamente, e que forem classificados em qualquer das praças de Marinheiros ou Inferiores, só serão obrigados a servir por tempo de seis anos; querendo porém continuar, gozarão das vantagens que oferece o Artigo antecedente, começando a vencer a gratificação da terça parte do soldo desde o dia em que completarem nove anos de serviço.

FONTE: Coleção de Leis do Império do Brasil, 1845.

7 Derroga o Decreto 304, de 2 de junho de 1843, e manda por em execução o Regulamento para o corpo dos imperiais marinheiros. Coleção de Leis do Império (CLI), 1845. 


\section{II - Decreto 1465 25/10/1854}

Art. $1^{\circ}$. As praças do Corpo de Imperiais Marinheiros, que ou forem recrutadas, ou para ele passarem das Companhias adidas de Aprendizes, terão direito

$\S 1^{\circ}$ No fim de dez anos de serviço, além do soldo correspondente às suas respectivas classes, a uma gratificação igual à terça parte do mesmo soldo. $\S 2^{\circ}$ No fim de dezesseis anos de serviço, à uma gratificação igual à metade do soldo.

$\S 3^{\circ}$ Tendo completado vinte anos de serviço, à reforma com soldo inteiro correspondente à classe em que se acharem.

Art. $2^{\circ}$ Os Imperiais Marinheiros que assentarem praça voluntariamente, e não procederem das Companhias de Aprendizes, somente serão obrigados a servir por tempo de seis anos, se entrarem para o Corpo em alguma das praças de Marinheiro, ou a obtiverem dentro do primeiro ano; e por tempo de dez anos se entrarem na praça de Grumete, e não passarem à de Marinheiro dentro do primeiro ano continuando no serviço, gozarão das vantagens que acima se concedem aos recrutados e aos Aprendizes Marinheiros.

Art. $3^{\circ}$ Os voluntários, de que trata o artigo anterior, começarão a vencer a gratificação da terça parte do soldo desde o dia em que declararem que querem continuar, tendo completado o seu tempo de serviço; e a gratificação da metade do soldo logo que tenham feito igual declaração, findo o prazo de dezesseis anos. Estas declarações podem ser sucessivamente renovadas, nunca, porém, por tempo menor de um ano. Aquele que não as fizer pode continuar no serviço por tempo indeterminado, mas não terá direito a qualquer das sobreditas gratificações.

Art. $4^{\circ} \mathrm{O}$ Imperial Marinheiro, dos compreendidos no artigo primeiro, que tiver como tal serviço por espaço de seis anos, e com bom comportamento, poderá obter até quatro anos de licença para empregar-se a bordo de navios mercantes nacionais. Esta licença somente será concedida por prazos de um a dois anos. Apresentando-se o licenciado, e sendo julgado capaz de todo o serviço, continuará na mesma classe em que se achava ao tempo da licença, e entrará no gozo das vantagens que pelo presente decreto e outras disposições vigentes se concedem aos Imperiais Marinheiros, deduzido o tempo da interrupção.

FONTE: Coleção de Leis do Império do Brasil, 1854.

8 Manda observar várias disposições relativas ao Corpo de Imperiais Marinheiros. CLI, 1854. 
Como se pode verificar pela leitura dos extratos do decreto 411 A de 1845, os praças recrutados e as oriundos das Companhias de Aprendizes Marinheiros, bem como os voluntários que assentassem praça como grumetes, estavam sujeitas a doze anos de serviço militar obrigatório no Corpo de Imperiais Marinheiros. Após esse período, se decidissem permanecer no corpo, passariam a receber uma gratificação de mais $1 / 3$ do soldo - que permaneciam os mesmos de 1845 - referente às respectivas classes e, com dezesseis anos de serviço, teriam direito à reforma com pensão igual a meio soldo. Já os voluntários assentados como marinheiros estavam sujeitos a seis anos de serviço obrigatório e, permanecendo no corpo, receberiam a mesma gratificação de $1 / 3$ quando completassem nove anos de serviço e, com dezesseis anos, também teriam direito à reforma com pensão igual a $1 / 2$ soldo.

O decreto 1465 de 1854 é de uma complexidade maior. Os praças recrutados ou oriundos das Companhias de Aprendizes Marinheiros prestariam vinte anos de serviço militar obrigatório, ao final dos quais seriam reformados com uma pensão igual ao valor integral do soldo correspondente às respectivas classes. A partir do décimo ano de serviço, passariam a receber uma gratificação igual a $1 / 3$ do soldo e, a partir do décimo sexto, de $1 / 2$ soldo. Além disso, tendo completado seis anos de serviço com bom comportamento, poderiam obter até quatro anos de licença para trabalharem em navios mercantes nacionais. Por sua vez, os voluntários prestariam serviço obrigatório por seis anos se entrassem para o corpo em alguma das praças de marinheiro ou a obtivessem em um ano. Caso entrassem em praça de Grumete, prestariam serviço obrigatório por dez anos. Permanecendo no serviço, teriam os mesmos direitos e benefícios que os recrutados e oriundos das Companhias de Aprendizes: ao final do sexto ou do décimo ano, conforme o caso, passariam a receber gratificação equivalente a $1 / 3$ do soldo e, ao final de dezesseis anos de serviço, gratificação equivalente a $1 /$ 2 soldo.

A seção de Guerra e Marinha, com base nessa comparação, concluiu que

...a lei vigente reduziu o tempo de serviço dos voluntários que são alistados na praça de grumete. (...) Aumentou o das outras praças, que hoje estão adstritas por vinte anos, quando antes o estavam por doze; mas esta ampliação é acompanhada de vantagens que não dava o regulamento de 1845, quais a 
gratificação no fim de dez anos, o acréscimo desta no fim de dezesseis, e a reforma com vencimento duplo, preenchido o prazo total.

Observava, ainda, que"entendem alguns que estas vantagens não compensam o acréscimo de anos, e que, longe disso, o sistema atual aterra e afugenta os cidadãos recrutáveis" (Consulta, p. 51). Segundo o entendimento dos conselheiros, este seria o pressuposto para se apresentarem propostas de reformas, como o haviam feito os praças, o encarregado do quartel general e o conselho naval. Notavam ainda os conselheiros que só havia acordo em condenar o sistema vigente.

Em seguida, a seção de Guerra e Marinha respondeu, um a um, os argumentos apresentados em favor das mudanças sugeridas, fossem pelos praças, pelo encarregado do quartel general e pelo conselho naval, a saber, o excessivo tempo de serviço: a) equiparado a castigo; b) responsável pelo grande número de desertores, c) igualado ao tempo útil de uma vida.

Respondendo ao argumento de que o prazo de vinte anos de serviço militar obrigatório não encontraria exemplo em outra nação, os conselheiros afirmavam que o contrário diziam os especialistas, conhecedores das forças militares da Europa. Segundo as informações coletadas, o tempo de serviço militar na Rússia seria de vinte anos e na Prússia não menos de dez anos. Ponderava a seção de Guerra e Marinha que não haveria um princípio universal sobre a questão, variando a constituição da força militar, assim como o tempo de serviço, segundo as peculiaridades de cada país. No Brasil, continuava o parecer, o maior prazo para os voluntários de primeiro alistamento (praças de marinheiros) era e sempre tinha sido o de seis anos. Fosse no Exército ou na Armada, somente os recrutados e os "jovens que são mantidos e educados pela nação para a vida militar" (Aprendizes Marinheiros) eram obrigados a prazos mais longos, e concluía: "Não procede, pois, o argumento histórico invocado contra as disposições em vigor na Armada e menos peso pode ainda merecer a repugnante comparação da sorte do imperial marinheiro com a dos condenados".

Os conselheiros afirmavam ser o alistamento de voluntários muito raro no Brasil, tendo já demonstrado a experiência que, independentemente da forma de ingresso, o marinheiro, apenas concluído o tempo de serviço, "retirava-se da Marinha de Guerra, e, o que é pior, fugia também da Marinha mercante, preferindo a vida de terra à de mar" (Consulta, p. 52). Foi 
introduzido, nesse momento, um argumento de fundo econômico: o custo de formação de um marinheiro era alto e, no entanto, desde sua criação, o corpo vinha se mantendo incompleto, situação que o governo não podia deixar de lamentar. Somava-se, ainda, o fato de que os marinheiros, ingressando no serviço ativo aos dezessete anos, eram reformados aos vinte e nove e abandonavam a profissão adquirida nas escolas: perdia o Estado, perdia a Marinha mercante. A solução encontrada para esses "problemas" havia sido o prolongamento do tempo de serviço militar obrigatório.

Para fundamentar o parecer, a seção de Guerra e Marinha recorreu às estatísticas apresentadas nos relatórios do Ministério da Marinha. Por eles se podia apurar que, em 1854, o corpo de marinheiros era composto por mil duzentos e quatro marinheiros e, em 1865, por dois mil setecentos e seis (Consulta, p. 52-53).

Impressiona, à primeira vista, constatar que os efetivos do corpo de marinheiros tivesse crescido $125 \%$ no espaço de onze anos. Porém, o questionamento lógico a ser feito dizia respeito à relação entre o prolongamento do tempo de serviço e o referido aumento dos efetivos. Usando de um artifício, a seção parecia querer esvaziar o conteúdo desse questionamento e até mesmo obliterar uma investigação mais aprofundada da questão. De fato, após a apresentação dos dados, concluía:

\footnotetext{
Pode ser que a prosperidade [do Corpo de Imperiais Marinheiros] (...) derive de causas especiais e independentes dos prazos de serviço. Mas também não se pode alegar o fato próspero da atualidade do corpo (...) como fundamento ou para a revogação ou derrogação das medidas de 1854 . Se o fato não prova a favor dessas providências, também não as desabona (Consulta, p. 53).
}

Discordar-se-á aqui, entretanto, dos ilustres conselheiros de Sua Majestade. Invertendo a proposição do problema, uma análise do ingresso no corpo de imperiais marinheiros permitirá constatar, ou não, o "sucesso" das medidas de 1854, bem como os fundamentos da reivindicação dos praças daquele corpo. A análise do ingresso permitirá também a verificação das modalidades de alistamento militar, bem como de sua movimentação ao longo do período em questão. 
Os dados, coligidos a partir dos relatórios dos ministros do período, são os seguintes:

\begin{tabular}{|l|c|c|}
\hline \multicolumn{3}{|c|}{ III - Ingresso de praças no Corpo de Imperiais Marinheiros } \\
\hline \multicolumn{1}{|c|}{ Modalidade } & $\begin{array}{c}1845-1854 \\
\text { Dec. 411- A }\end{array}$ & $\begin{array}{c}1855-1866 \\
\text { Dec. 1465 }\end{array}$ \\
\hline Recrutamento & 1357 & 2935 \\
\hline Companhias de Aprendizes Marinheiros & 683 & 1336 \\
\hline Voluntários & 91 & 87 \\
\hline Transferidos de outros corpos & 06 & 11 \\
\hline Substituição & 01 & 02 \\
\hline Total & 2138 & 4371 \\
\hline
\end{tabular}

FONTE: Mapa Estatístico do Corpo de Imperiais Marinheiros. $R M M, 1867$, anexo. ${ }^{9}$

Comparando-se os dois períodos (vigência do decreto 411-A; vigência do decreto 1465 até a elaboração do requerimento), pode-se constatar que o número de praças oriundos do recrutamento forçado cresceu em torno de $116 \%$, e o dos provenientes das escolas de aprendizes marinheiros $95 \%$. Por outro lado, o voluntariado, já insignificante no primeiro período, diminuiu $0,44 \%$ no segundo. As transferências de outros corpos militares aumentou levemente e a substituição praticamente inexistiu nos dois períodos. Para uma melhor visualização do problema é necessário, ainda, considerar-se a distribuição anual do ingresso de praças:

\begin{tabular}{|c|c|c|c|c|c|c|}
\hline \multicolumn{7}{|c|}{ IV - Ingresso no Corpo de Imperiais Marinheiros - Movimento Anual } \\
\hline & Recrut. & EAM & Volunt. & Transf. & Substit. & Total \\
\hline 1845 & 152 & 101 & 15 & 01 & - & 269 \\
\hline 1846 & 160 & 71 & 39 & 01 & - & 271 \\
\hline 1847 & 107 & 27 & 04 & - & - & 138 \\
\hline 1848 & 169 & 95 & 04 & 02 & - & 270 \\
\hline 1849 & 202 & 42 & 05 & 01 & - & 250 \\
\hline 1850 & 250 & 68 & 01 & - & - & 319 \\
\hline 1851 & 149 & 64 & 13 & - & 01 & 227 \\
\hline 1852 & 84 & 87 & 03 & 01 & - & 175 \\
\hline 1853 & 20 & 62 & 06 & - & - & 88 \\
\hline 1854 & 64 & 66 & 01 & - & - & 131 \\
\hline 1855 & 64 & 58 & 05 & - & - & 127 \\
\hline
\end{tabular}

9 A partir da década de 1860, os relatórios do ministério da Marinha passaram a apresentar em anexo um mapa estatístico do corpo de imperiais marinheiros, contendo os dados de ingresso, mortes, desligamentos, baixas e deserções, que nos relatórios anteriores encontravam-se esparsos. 


\begin{tabular}{|c|c|c|c|c|c|c|}
\hline 1856 & 70 & 45 & 02 & - & - & 117 \\
\hline 1857 & 220 & 34 & 02 & 02 & 01 & 259 \\
\hline 1858 & 206 & 26 & - & - & 01 & 233 \\
\hline 1859 & 202 & 70 & 08 & - & - & 280 \\
\hline 1860 & 191 & 103 & - & - & - & 294 \\
\hline 1861 & 131 & 142 & - & - & - & 273 \\
\hline 1862 & 211 & 154 & - & - & - & 365 \\
\hline 1863 & 144 & 113 & 04 & - & - & 261 \\
\hline 1864 & 205 & 132 & 13 & - & - & 350 \\
\hline 1865 & 851 & 220 & 46 & 09 & - & 1126 \\
\hline 1866 & 440 & 239 & 07 & - & - & 686 \\
\hline Total & 4292 & 2019 & 178 & 17 & 03 & 6509 \\
\hline
\end{tabular}

FONTE: Mapa Estatístico do Corpo de Imperiais Marinheiros. RMM, 1867, anexo.

Os dados sugerem algumas reflexões. Em primeiro lugar, constata-se que a alteração da lei de 1845 não alterou fundamentalmente o movimento de ingresso de praças no corpo de marinheiros, composto basicamente pelos recrutados $(66 \%)$ e pelos oriundos das escolas de aprendizes (31\%). Os voluntários corresponderam a apenas $2,7 \%$ do total global de assentamentos ao longo desses vinte e dois anos, os transferidos a $0,26 \%$, e os substitutos a $0,04 \%$. Já foi constatado que durante a vigência do decreto 1465 houve um crescimento no recrutamento.

Um olhar mais particularizado permite verificar que nos anos de 1865 e 1866, ou seja, no início da guerra com o Paraguai, o recrutamento constituiu-se em verdadeira razia. Se, por um lado, isto não é exatamente uma novidade - a memória e a historiografia da guerra já denunciou enfaticamente a violência inaudita do recrutamento no período -, por outro, pode contribuir para explicar a emergência do movimento dos praças. Podese verificar, também, como era insignificante o número de praças voluntários que seriam - para usar dos termos da lei - "beneficiadas com as vantagens" que a legislação oferecia.

A seção de Guerra e Marinha não mencionava, portanto, que a "prosperidade" do corpo de marinheiros derivava única e exclusivamente do recrutamento forçado, que obrigava os praças a vinte anos de serviço, daí o fundamento e a razão do requerimento.

Por outro lado, os conselheiros pretenderam, também com base nas estatísticas, demonstrar que o argumento do capitão de mar e guerra Elisário Antonio dos Santos, comandante do Corpo de Imperiais Marinheiros, atribuindo ao novo decreto o aumento do número de praças que desertam do serviço militar, não era procedente. É fundamental verificar como 
esse argumento foi construído. Os dados apresentados pela seção de Guerra e Marinha eram os seguintes:

\begin{tabular}{|l|c|c|}
\hline \multicolumn{3}{|c|}{ V -Alistamento/deserções - Corpo de Imperais Marinheiros } \\
\hline & $1836-1854$ & $1855-1865$ \\
\hline Alistaram-se & 2913 & 3814 \\
\hline Desertaram & 1668 & 1706 \\
\hline Apresentados/Capturados & 717 & 896 \\
\hline Perda efetiva & 951 & 810 \\
\hline
\end{tabular}

FONTE: Consulta da seção de Guerra e Marinha, p. 53.

A primeira indagação acerca do quadro diz respeito à sua periodização: por que os conselheiros optaram por apresentar os dados a partir de 1836 e não de 1845 , uma vez que o requerimento dizia respeito aos dispositivos daquele ano?

Eles afirmavam que "o corpo de imperiais marinheiros foi criado pela lei 42 de 15 de outubro de 1836", sem outras explicações. O corpo foi, contudo, criado somente em $1840,{ }^{11}$ e seu primeiro regulamento "militar" data de 1843 , tendo sido reformulado em 1845 . Por outro lado, a comparação que os conselheiros fizeram, relativa ao aumento do número de praças, fora baseada em dados de 1845 . Por que então a mudança?

Para responder a isso deve-se estabelecer uma outra comparação. Dos dados referentes aos anos de 1836 a 1865, divididos em dois períodos (1836-1854/ 1855-1865) a seção de Guerra e Marinha concluía:

$1^{\circ}$ - Que o número de alistamentos foi menor no primeiro período do que no segundo; $2^{\circ}$ - Que o número de deserções, comparado com o dos alistamentos, foi 0,57 deste no primeiro período, e 0,44 no segundo; $3^{\circ}$ - Que a perda efetiva, por deserções, foi maior no primeiro do que no segundo período, na razão de 951 para 810. A estatística das deserções, portanto, não pode justificar a reforma pretendida e aconselhada (Consulta, p. 53).

11 Em 1836, o ministro Salvador José Maciel criou, baseado nas idéias de Rodrigues Torres, as companhias fixas de marinheiros, onde deveriam servir "todos os rapazes sem meios de subsistência, e os que não se aplicarem assiduamente à algum ofício ou ocupação; estes corpos devem ser organizados de tal forma, que se tornem aptos para todo o serviço de mar, e aprendam conjuntamente o manejo de artilharia, de fuzil e de todas as armas, que se usam nos combates navais e nos de terra". Maciel justificava a criação dessas companhias pela necessidade de supressão do engajamento - dispendioso - e do recrutamento opressivo e destruidor da navegação costeira e da pesca, pois basicamente incidia sobre os que trabalhavam nessas atividades. Cf. ARIAS NETO, op. cit., p. 58. 
Refazendo-se a distribuição dos dados com base nas mesmas fontes utilizadas pela seção de Guerra e Marinha, considerando-se, porém, o período de 1845 a 1866, o resultado apresenta algumas diferenças.

\begin{tabular}{|l|c|c|c|}
\hline \multicolumn{4}{|c|}{ VI - Deserções - Corpo de Imperiais Marinheiros } \\
\hline & $1845-1854$ & $1855-1866$ & Total \\
\hline Desertores & 1501 & 1779 & 3280 \\
\hline Apresentados/Capturados & 652 & 936 & 1588 \\
\hline Existentes & 849 & 843 & 1692 \\
\hline
\end{tabular}

FONTE: Mapa Estatístico do Corpo de Imperiais Marinheiros. RMM, 1867, anexo.

Percebe-se, pelos dados reordenados, que houve significativa variação de 4 pontos percentuais no número de desertores entre o primeiro período (23\% em relação ao total de ingressos) e o segundo (27\%), sendo, portanto, de 50\% o índice total de deserção entre os anos de 1845 e 1866. Verifica-se, também, que a taxa total de desertores não capturados era de $26 \%$ ao longo dos anos de 1845 a 1866.

Se os dados não permitem relacionar o alto índice de deserção às mudanças promovidas, possibilitam, por outro lado, afirmar que após 1854 o índice de deserção sofreu significativa alta, o que pode ser atribuído à expansão do tempo de serviço militar obrigatório, como fez o capitão Elisário dos Santos. Reforça essa suposição, também, o fato de que o índice de captura elevou-se significativamente no segundo período ( $29 \%$ do total de desertores) em relação ao primeiro (20\%).

Pode-se verificar, portanto, que no momento em que o Estado procurava coibir o tráfico negreiro e ao mesmo tempo as tensões no Prata haviam se tornado bastante graves, ou seja, em um momento de grande instabilidade nas relações externas do Império, não apenas o recrutamento, como também o reapresamento, ou em outras palavras, a caça aos desertores haviam sido bastante amplificados.

É possível compreender o mecanismo de dissimulação empregado pelos conselheiros do imperador: a diluição dos dados de deserção entre os anos de 1836 a 1865 e a concentração dos dados de ingresso entre os anos de 1845 e 1865, visava ocultar o fato do índice de deserção haver aumentado 9\%, comparativamente ao período de vigência do decreto 411 A. Isso também poderia explicar porque não foram incorporados os dados de 1866, já divulgados no relatório do ministro da Marinha em maio, quando a seção realizava seu trabalho de análise do requerimento dos praças. 
Finalmente, a seção de Guerra e Marinha introduziu um terceiro elemento para negar a validade do requerimento: o número de voluntários. Aqui o mecanismo foi o mesmo: apresentou os dados a partir de 1836 a 1865, para concluir: "que de 1836 a 1854 alistaram-se 130 voluntários no Corpo de Imperiais Marinheiros; e 77, de 1855 a 1865. A diferença não é grande; e converte-se a favor do segundo período, levando-se em conta que este abrange dez anos e o outro dezoito anos" (Consulta, p. 53). Como já se verificou, no entanto, os dados referentes ao período de 1845-1854 e 18551866 mostram que alistaram-se 91 voluntários no primeiro período e 87 no segundo, o que mais uma vez desmente a seção de Guerra e Marinha. Os conselheiros não acreditavam que, quer elevando as "vantagens pecuniárias", quer reduzindo o tempo de serviço, fosse possível se resolver satisfatoriamente os problemas do baixo número de voluntários ou do alto índice de deserções.

Consideraram, ainda, o último argumento dos requerentes - que o serviço militar absorve-lhes todo o vigor de seus anos, e só os deixa quando de todo incapazes para outra ocupação - manifestamente exagerado. Segundo eles, os aprendizes ingressavam no corpo com a idade de dezesseis a dezessete anos, podendo retirar-se aos trinta e sete - uma idade que não se podia caracterizar como sendo de invalidez - gozando de pensão igual ao soldo referente ao posto em que foram reformados. Afirmavam, ainda, que os aprendizes, em sua maior parte, eram órfãos e desvalidos quando entravam para as escolas e não tinham razão para queixar-se de o Estado que os mantinha e educava, além dos prêmios a muitos deles abonados pelo alistamento - exigir-lhes vinte anos de serviço na Armada, serviço honroso e retribuído, do qual saíam possuindo uma profissão que, juntamente com a pensão, lhes garantia um abrigo contra a miséria.

O menor tempo de serviço para os voluntários era um estímulo julgado necessário para se atrair marinheiros, uma profissão - que não podia ser considerada como ônus - lucrativa, honrosa e "mais seguro que tantos outros em que aliás se consomem os anos de uma existência inteira" (Consulta, p. 54).

Quanto aos praças de marinhagem recrutados, os conselheiros observavam que até 1854 não tinham tempo determinado de serviço, ou seja, eram obrigados a servir enquanto vivessem ou enquanto o governo quisesse. O decreto 1465 fixou-lhes tempo de serviço e não se levantaram quei- 
xas "e menos apareceram petições coletivas contra a sorte desses indivíduos, posto que estes não gozassem das vantagens de que hoje gozam os Imperais Marinheiros" (Consulta, p. 54).

Afirmavam também que o decreto 1465 poderia ser melhorado ou mesmo reformado radicalmente, mas que, tendo em vista a história das últimas disposições, não se poderia formar juízo seguro sobre a necessidade de reformas e sobre a conveniência das sugestões apresentadas pelas várias instâncias: praças, quartel general e conselho naval.

Para concluir seu parecer sobre a questão, a seção de Guerra e Marinha voltava-se contra a aplicação de soluções "simplistas", constatando, para mais uma vez negar os termos do requerimento, a grande complexidade da questão:

O problema é muito complexo, e talvez que sua verdadeira solução esteja não em uma, mas em uma série de medidas, que, bem concebidas e zelosamente executadas, elevem a condição moral do marinheiro militar aos seus próprios olhos e no apreço da sociedade em que vivem, ao mesmo tempo que lhe garantam vantagens que guardem uma justa proporção com a liberdade e soldadas da Marinha mercante. O regresso puro e simples, como desejam os peticionários às disposições do regulamento de 1845 , encontra o fundado receio de que o corpo de imperiais marinheiros decaia do seu estado atual para o que era antes de 1854 (Consulta, p. 54).

Os argumentos até o momento reunidos, permitem verificar a existência de duas imagens opostas. De um lado os peticionários viam o serviço militar na Armada como castigo que resultava na exaustão de seus corpos, de sua expectativa de vida, especialmente com um tempo obrigatório de vinte anos e, como prova de suas afirmações, invocavam o aumento no já grande número de deserções que ocorriam no corpo. Assim, reivindicavam apenas o retorno dos dispositivos de 1845, que reduziam para doze anos o tempo de serviço militar obrigatório, reivindicação que os superiores hierárquicos, o conselho naval e o próprio ministro da Marinha reconheciam como justas. Por outro lado, a seção de Guerra e Marinha, ou ao menos os conselheiros Nabuco e Paranhos, para negar a validade do argumento apresentado, manipularam uma série de dados estatísticos, buscando compro- 
var que os efetivos do corpo não apenas haviam se elevado, como não era possível vincular o aumento no índice de deserção à extensão do tempo de serviço obrigatório. Continuando na sua argumentação, afirmavam que o Estado mantinha e educava os aprendizes e marinheiros a um alto custo e, nesse sentido, era razoável a exigência de vinte anos de serviço na Armada, atividade honrosa e retribuída, que proporcionava aqueles homens uma profissão e pensões que lhes punham ao abrigo da miséria. Era, portanto, repugnante a associação entre serviço militar e pena de grandes criminosos. Finalmente, Nabuco e Paranhos reconheciam a complexidade da questão somente para negar a validade do requerimento e da concordância das autoridades da Marinha, qualificando as soluções propostas como "simplistas". Nesse raciocínio concluíam que talvez a solução para "elevar a condição moral do marinheiro militar aos seus próprios olhos e no apreço da sociedade (...) e ao mesmo tempo que lhe [garantissem] vantagens que [guardassem] uma justa proporção com a liberdade e soldadas da Marinha mercante" fosse não uma, mas um conjunto de medidas bem concebidas e executadas (grifos meus). A própria sessão reconhecia, portanto, que as condições de trabalho na Marinha mercante eram superiores aos da Marinha de Guerra, quer quanto aos vencimentos, quer quanto à liberdade, idéia que pode ser interpretada de muitos modos.

Essa discussão permite ainda algumas indagações: a) por que o índice de deserção era alto? b) por que os marinheiros referiam-se à sua situação ao fim de vinte anos de serviço militar como sendo de "inutilizados"? c) embora repugne aos conselheiros de Sua Majestade, a questão é pertinente: seria o serviço militar uma condenação? Estas interrogações que nascem do documento, demandam uma certa reflexão. Para desenvolvêla, utilizar-se-á alguns dados do próprio ministério da Marinha, os quais também dispunha a seção.

Agrupando-se os dados referentes às baixas do corpo de marinheiros no período, tem-se o seguinte quadro: 


\begin{tabular}{|l|c|c|c|c|c|c|}
\hline \multicolumn{7}{|c|}{ VII - Baixas - Corpo de Imperiais Marinheiros } \\
\hline & \multicolumn{1}{|c|}{$1845-1854$} & \multicolumn{1}{c|}{$1855-1866$} & \multicolumn{2}{c|}{ Total } \\
\hline & $\mathrm{n}^{\text {o }}$ & $\%$ & $\mathrm{n}^{\text {o }}$ & $\%$ & $\mathrm{n}^{\text {o }}$ & $\%$ \\
\hline Morte por doenças & 436 & 53,4 & 596 & 35,1 & 1032 & 41,1 \\
\hline Morte por desastres & - & - & 114 & 6,7 & 114 & 4,6 \\
\hline Morte por combates & - & - & 51 & 3,0 & 51 & 2,0 \\
\hline Reforma & 09 & 1,1 & 33 & 1,9 & 42 & 1,7 \\
\hline Extraviados & - & - & 05 & 0,3 & 05 & 0,1 \\
\hline Por serem escravos ${ }^{13}$ & - & - & 12 & 0,7 & 12 & 0,4 \\
\hline Morte por execução & 01 & 0,1 & 02 & 0,1 & 03 & 0,1 \\
\hline Transf. - outros corpos & 42 & 5,2 & 52 & 3,1 & 94 & 3,8 \\
\hline Asilo de inválidos & 18 & 2,2 & 28 & 1,7 & 46 & 1,9 \\
\hline Por completar o tempo & 60 & 7,4 & 406 & 24,0 & 466 & 18,6 \\
\hline Substituição & 01 & 0,1 & 02 & 0,1 & 03 & 0,1 \\
\hline Inspeção & 149 & 18,3 & 289 & 17,1 & 438 & 17,4 \\
\hline Sentença & 12 & 1,5 & 21 & 1,2 & 33 & 1,4 \\
\hline Isenção legal $^{14}$ & 87 & 10,7 & 83 & 5,0 & 170 & 6,8 \\
\hline Estrangeiros $^{15}$ & - & - & 01 & - & 01 & - \\
\hline Total & 815 & 100,0 & 1695 & 100,0 & 2510 & 100,0 \\
\hline
\end{tabular}

FONTE: Mapa Estatístico do Corpo de Imperiais Marinheiros. RMM, 1867, anexo.

13 A presença de escravos ou libertos era pequena tanto no Exército como na Armada, mesmo durante a guerra. Cálculos recentes - com bases em estimativas aproximativas - têm evidenciado que uma parcela mínima do exército combatente era formada por escravos e libertos, em números que variam de 5,5 a 6,9\%, conforme a fonte adotada. Tratava-se, portanto, como observa André Toral, muito mais de um processo de exclusão social, posto que "os limites da cidadania efetiva do Império iguala os escravos e despossuídos como material humano disponível para a guerra”. TORAL, A. A. de. A participação dos escravos negros na Guerra do Paraguai. Estudos Avançados, São Paulo, v. 9, n. 24, p. 287-298, maio/ago. 1995. Essa situação também é constatada no que diz respeito à Marinha. Em 1865, o governo objetivando, mediante a emergência da guerra, complementar os claros do Corpo de Imperiais Marinheiros e do batalhão naval, libertou escravos para assentarem praça. Embora essa última medida tenha gerado acres críticas na Câmara, dos dois mil e setenta e dois libertos pelo ministério da Marinha, a maioria foi transferida para o Exército. O mapa estatístico do Corpo de Imperiais Marinheiros registra, de fato, o assentamento de apenas trezentos e sete libertos entre os anos de 1845 e 1888, trinta e oito em 1867, duzentos e cinqüenta e seis em 1868 e treze em 1883. Considerando-se que o efetivo total de marinheiros do corpo no ano de 1868 era de três mil quatrocentos e oitenta e três, o número de libertos perfazia um total de 7,3\%, um índice percentual levemente superior aos apresentados no Exército, mas dentro da mesma média. Porém, se comparados ao total de sete mil trezentos e cinqüenta e três marinheiros existentes na Armada no mesmo ano, considerados também a marinhagem avulsa contratada e recrutada, o índice decai para 3,5\%. As próprias condições do mercado escravista - drasticamente afetado pela abolição do tráfico de 1850 - parece ter sido uma determinante estrutural dessa ausência.

14 Em 1851, o decreto 1591 "manda observar instruções por que deve ser feito o alistamento de voluntários e de recrutas para o serviço da Armada", estabelecia que somente cidadãos seriam recrutados e também as isenções legais 1) casados ou viúvos com filhas ou filhos menores; 2) os filhos de viúva ou viúvo, cuja subsistência estivessem ao seu cargo; 3) irmãos que sustentassem irmãos menores; 4) menores de dezoito anos empregados como praticantes em navios de comércio; 5) calafates e carpinteiros; 6) patrões de barcos nacionais que se empregarem em conduzir mantimentos ou na pesca; 7) os que tiverem servido como voluntários (isenção temporária); 8) aqueles que possuírem concessão em virtude de autorização da assembléia geral (Decreto 1591 de 14/04/1855 arts. 26 a 29. Anexo ao RMM, 1855). Essas isenções foram suspensas 
É possível perceber, através do quadro de baixas, que o serviço da Armada não correspondia àquela representação de "honroso" e "retribuído", bem como àquela emanada dos relatórios dos ministros, como já se viu, sobre o corpo de marinheiros como um instituto de "formação", um "asilo" para a infância desvalida. Muito menos ainda seria possível qualificar a deserção enquanto vício herdado da Marinha portuguesa, como havia feito o chefe do quartel general da Armada em 1856 (RMM,1856).

Os índices indicativos da expectativa de vida revelam que, no período de 1845-1866, 58,1\% das baixas no corpo de imperiais marinheiros deveram-se à mortes por doenças e por inspeção de saúde ou, na linguagem dos conselheiros, às "inutilizações". Se incluir-se as mortes por desastres e combates, o índice eleva-se para 64,7\%. Esses dados permitem imaginar que as condições sanitárias e o regime alimentar à bordo dos navios e nos quartéis eram precaríssimos. ${ }^{16}$ Por outro lado, apenas $1,7 \%$ dos ingressos obtiveram reforma final com as "vantagens" asseguradas pela lei, enquanto $18,6 \%$ simplesmente deixaram o corpo assim que completaram o tempo mínimo de serviço militar. Ou seja, tomando-se as estatísticas do Ministério da Marinha, verifica-se que, do total de Imperiais Marinheiros existen-

em 1866, durante a guerra do Paraguai. Através do decreto 3708, de 19 de setembro de 1866, foram "chamados" ao serviço da Armada mil e seiscentos indivíduos empregados na vida do mar e matriculados nas capitanias dos portos. Decisão 427, de 4 de outubro, que dá as instruções para a execução do decreto, estabelece que " $\$ 2^{\circ}$ - Entre os indivíduos que fazem profissão na vida do mar, ou que como tais se achem matriculados nas capitanias dos portos, serão designados de preferência, o solteiros; e na falta destes em número suficiente para completar os contingentes: $1^{\circ}$ - os menores de 18 e maiores de 16 anos que se achem empregados como praticantes de navios nacionais; $2^{\circ}$ - os irmãos que sustentarem irmãos menores; $3^{\circ}$ - os filhos de viúva ou viúvo cuja subsistência esteja a seu cargo; $4^{\circ}$ - os casados ou viúvos com filhas ou filhos menores $\$ 3^{\circ}$ - Só depois de esgotada uma das classes acima declaradas, se poderá passar a designar na imediata." CLI, 1866.

15 O mesmo decreto 1591 , permite a contratação de estrangeiros quando autorizado pela Assembléia, em circunstâncias especiais.

16 Em 1850, o ministro Tosta, informava, no seu relatório, que mil duzentos e sessenta e quatro praças haviam sido internados no hospital de Marinha com febre amarela, dos quais sessenta morreram. Essa é, entretanto, uma circunstância, mais ou menos extraordinária, devido à epidemia que atingiu todo o país. Por outro lado, verificando-se os mapas dos doentes tratados nos hospitais e enfermarias provinciais que começaram a ser estabelecidas por volta de 1851, pode-se fazer uma idéia das condições sanitárias e das doenças mais comuns. Em 1854, foram tratados na Armada (incluindo-se os avulsos) quatro mil oitocentos e setenta e quatro doentes, dos quais oitocentos e setenta e nove com doenças pulmonares (bronquites, pneumonias e tuberculose); seiscentos e cinqüenta e seis com doenças sifilíticas, trezentos e setenta e cinco com febres (amarela, tifóide e outras); trezentos e noventa e seis com afeções reumáticas e cento e trinta e três com sarna. Dez anos mais tarde, em 1864, foram tratados cinco mil oitocentos e noventa e quatro doentes, dos quais mil cento e quatro com doenças sifilíticas, novecentos e setenta e um com doenças respiratórias, trezentos e sessenta e seis com febres, trezentos e sete com reumatismo e trezentos e vinte e dois 
tes no corpo, no período de 1845-1866, 47,7\% morreram, em sua maioria absoluta por doenças, e 17,4\% foram desligados por "inutilizados", enquanto que apenas $20,3 \%$ chegaram a completar o tempo de serviço mínimo ou foram reformados. As variações entre um período e outro são, por assim dizer, insignificantes. Destaca-se, no entanto, o grande número de marinheiros que se desligaram por completar o tempo, ainda vinculados ao regime de doze anos de serviço obrigatório.

É verdade que os dados, especialmente os sanitários que refletem um alto índice de mortalidade, podem ser relacionados com as condições gerais do país no período e não seriam uma característica específica da Armada. Por outro lado, não se pode elidir certas particularidades da vida de bordo: os navios passavam dias e dias navegando, especialmente os veleiros e os navios de sistema misto que, como os primeiros, não dependiam de abastecimento regular de combustível. Além da faina do trabalho diuturno para movimentar o navio e fazer os reparos necessários, o espaço deveria ser reservado para armamentos e munições. No caso dos vapores mistos, como se viu, o espaço do navio foi reduzido para dar lugar às máquinas e à lenha ou ao carvão. Em suma: os alimentos e a água eram reduzidos e rapidamente se deterioravam, o alojamento era precário, a ventilação praticamente não existia. Em outras palavras, certos aspectos sanitários constituem elementos que permitem compreender a caracterização da vida no mar como "áspera", como vida que ao cabo de alguns anos "inutilizava" os homens. ${ }^{17}$

com sarna (relatórios dos anos de 1854 e 1864). Verifica-se, portanto, que as doenças respiratórias, venéreas, febres e reumatismo eram as mais comuns durante o período. Significativo também é a permanência do grande número de doentes atendidos ao longo do período. É claro que essa situação não estava de modo algum desvinculada da absoluta insalubridade das cidades portuárias brasileiras. Sobre a questão ver: CHALHOUB, S. Cidade febril. São Paulo: Cia. das Letras, 1996. Por outro lado, a alimentação era bastante precária. De acordo com a tabela de dietas, que no período era denominada "ração", era destinado à alimentação semanal de um marinheiro (almoço, jantar e café): $459 \mathrm{~g}$ de açúcar; $133,8 \mathrm{~g}$ de café; 1,8 kg de carne fresca; 343, $2 \mathrm{~g}$ de carne seca; 668, $5 \mathrm{~g}$ de pão; $10,7 \mathrm{~g}$ de toucinho; $800 \mathrm{~g}$ de arroz; 0,6 litros de canjica; 2,5 litros de farinha; $229 \mathrm{~g}$ de bacalhau; 0,5 litros de legumes; 0,2 litros de sal e 35 réis destinados à compra de verduras. Essa alimentação era levemente incrementada quando o navio estava em viagem. Decreto $411 \mathrm{~A}$ de 05/06/1845. CLI, 1845.

17 Há uma ampla literatura que trata desses aspectos da vida marítima, da qual pode-se mencionar: GREENHALGH, J. O arsenal de marinha do Rio de Janeiro na História (1822-1889). Rio de Janeiro: Arsenal de Marinha, 1965; MARTINS, H. L. A revolta dos marinheiros: 1910. Rio de Janeiro: Serviço de Documentação Geral da Marinha, 1988; RITCHIE, R. C. Capitão Kidd e a guerra contra os piratas. Rio de Janeiro: Campus, 1989; RODRIGUES, J. Cultura marítima: marinheiros e escravos no tráfico negreiro para o Brasil (sécs. XVIII e XIX). Revista Brasileira de História, São Paulo, v. 19, n. 38, p. 15-53, 1999. 
Os dados de expectativa de vida parecem esclarecer, portanto, algumas das razões da repugnância que tinha a população em relação ao serviço militar na Armada. Talvez seja o momento de se considerar que a expressão "alto índice de deserção" - que descreve ao mesmo tempo a definição jurídica do crime e a forma como o Estado avaliava a questão seja insuficiente, do ponto de vista da história social, para designar um quadro de fuga generalizada do serviço militar na Armada.

A argumentação dos conselheiros de Estado descreve, portanto, um movimento de relativização que visa esvaziar o conteúdo do requerimento das praças, bem como das sugestões de reformas apresentadas pelo encarregado do quartel general e pelo conselho naval. Nesse processo, o raciocínio desenvolvido pelos conselheiros dissimula as condições gerais dos praças e, em uma leitura feita às avessas, verifica-se que além de estarem sujeitos a um tempo de serviço espantosamente prolongado, os marinheiros militares tinham vencimentos abaixo daqueles que se dedicavam à Marinha mercante, bem como estavam sujeitos a processos disciplinares mais rígidos. Mais do que isso, no entanto, o raciocínio da seção de Guerra e Marinha descreve um círculo que parte do pressuposto da lei e a ele retorna para negar o que explicitamente está posto no requerimento: que o serviço militar em si, na sua natureza própria, como foi constituído e organizado era a pena maior, em outras palavras, era uma condenação à morte para metade dos que nele ingressassem. Quem sobrevivia, ficava encerrado em uma prisão. E, por isso mesmo, o problema levantado pelo requerimento dos praças atingia o âmago do próprio sistema ou seja, representava o desejo de sair mais rapidamente da prisão, da enorme nau presiganga - a nau dos condenados - do grande navio tumbeiro que era a Armada Nacional. ${ }^{18}$ Dito de outro modo, o serviço militar representava em si a negação do direito mais elementar consagrado pelo liberalismo moderno: o direito à vida e, consequentemente, à liberdade, condição fundamental da cidadania.

18 Informa Juvenal Greenhalg que a questão acerca da sujeição dos artífices militares do arsenal aos regulamentos e códigos militares foi controversa. Em 1845, o Conselho Supremo Militar entendia que sim; em 1858 o Conselho de Estado pensava que não. A controvérsia ficou resolvida pelo decreto 3813, de 16 de março de 1867 (!), que determinou: "As praças das companhias militares, não estando sujeitas às leis militares da Armada e muito menos ao regulamento do corpo de imperiais marinheiros, serão punidas em suas faltas e delitos com as penas de: baixa, expulsão do serviço do Estado e recrutamento para os corpos e navios da mesma Armada”. Cf. GREENHALG, op. cit., p. 146-147. 
Daí a repugnância dos conselheiros com a associação feita no requerimento entre serviço militar e penalização e, por isso, a solução indicada pela seção foi a de manter inalteradas as disposições vigentes. Projetavase, em um futuro indefinido e improvável, uma mudança no processo de constituição das guarnições de Marinha.

É necessário, ainda, considerar que ao longo do período uma série de distinções foram sendo estabelecidas na aplicação dos castigos físicos, ou seja, no exercício da violência do Estado sobre o corpo do cidadão.

A deserção passou, desde 1833, a ser punida de acordo com o Artigo 80 dos de Guerra, ${ }^{19}$ mediante o "prudente arbítrio do superior". Com a implantação do regimento do corpo de imperiais marinheiros, as primeiras e segundas deserções continuaram a ser punidas pelo Artigo 80, enquanto que a partir da terceira, segundo o artigo 51, cinco anos de galés em tempo de guerra e um ano de serviços sem soldo em tempo de paz.

A partir de 1852, quando o corpo de fuzileiros foi transformado no batalhão naval, os praças dessa unidade deixaram de ser castigados correcionalmente em público, sendo a punição ministrada no alojamento do corpo. ${ }^{20} \mathrm{Em} \mathrm{1854,} \mathrm{com} \mathrm{as} \mathrm{reformas} \mathrm{introduzidas} \mathrm{por} \mathrm{Paranhos,} \mathrm{estabe-}$ leceu-se que, para os crimes de terceira e demais deserções, haveria, além das penas já consignadas, a perda do tempo de serviço anterior,${ }^{21}$ ou seja, criava-se mais uma forma de prender o cidadão ao serviço militar. Em 1863, o novo regulamento do corpo de oficiais marinheiros isentava-os dos castigos de golilha e prisão a ferros no porão, substituídos por prisão no alojamento e detenção à bordo. ${ }^{22}$

19 Durante todo o período monárquico a legislação militar da Armada era composta pelo Regimento Provisional e pelos Artigos de Guerra, antigos códigos da Marinha Portuguesa (1799), cuja função era a regulamentação da justiça militar, do trabalho e disciplina de bordo. Embora seja possível esse corpo de leis como possuindo um sentido disciplinar nos termos de Michel Foucault, a sua aplicação na Marinha Brasileira transformou-se em um sistema de suplícios, no qual os castigos corporais, especialmente a chibata, eram empregados ritualmente, representando a vingança do Rei sobre o corpo do cidadão. Ver: FOUCAULT, M. Vigiar e punir. 9. ed. Petrópolis: Vozes, 1987. A deserção em Portugal, segundo esse corpo legislativo, era punida em Portugal com a prisão e a suspensão de vencimentos. Desde o período regencial, quando as revoltas provinciais exigiam uma Armada eficiente, o Ministro da Marinha de então, Joaquim José Rodrigues Torres (mais tarde Visconde de Itaboraí), autorizou sua punição segundo os termos do Artigo 80 dos de Guerra. Cf. ARIAS NETO, op. cit. Especialmente o capítulo I , "A Armada Imperial: cidadania, recrutamento e suplícios."

20 Decreto 1067, de 24/11/1852, art. 32. Reproduzido na Ordem Geral 19, de 18/12/1852.

21 Decreto 1591, de 11/04/1855, art. 24. Anexo ao RMM, 1855.

22 Decreto 3208, de 24/12/1863, art. 5. CLI, 1863. 
A legislação, se cumprida, terminava por limitar a aplicação pública dos castigos corporais aos praças do Corpo de Imperais Marinheiros. Por outro lado, na medida em que manteve a regulamentação da punição ao arbítrio dos superiores, parece ter mantido também os excessos e abusos no emprego dos castigos corporais, que, cada vez mais, se tornaram uma vingança supliciante, corroendo completamente toda a economia da correção exemplar, baseada na proporcionalidade das penas e dos delitos, conforme estabelecido no Regimento Provisional e nos Artigos de Guerra. Na própria documentação oficial, há indícios significativos desse fenômeno.

Em 1854, o cirurgião-mór da Armada, na sua estatística dos doentes tratados nas enfermarias e navios - repassada anualmente ao quartel general para a inclusão no relatório do ministro -, deixava escapar indiscreto, a informação de que cento e dezessete praças haviam sido atendidas com contusões por castigo à bordo dos navios. Nos dados do mesmo ano, referente ao hospital de Marinha da Corte, apareciam dois praças atendidos com contusões por castigos. É muito provável que essa "revelação" tenha causado um certo mal-estar às autoridades, pois os mapas seguintes passaram a discriminar apenas as "contusões", sem nenhuma especificação. Estas, entretanto, continuaram a aparecer em elevado número: $243 \mathrm{em} 1864$, 246 em 1865, 126 em 1866, ano em que foi elaborado o requerimento.

Que os excessos e abusos eram conhecidos das autoridades, indicam algumas medidas tomadas após o "período da conciliação". Em 1861, o aviso de 13 de setembro voltava a determinar o que era estabelecido em lei:

S. M. o imperador, determina que só o encarregado do quartel general da Marinha, os comandantes das estações navais, dos navios e corpos de Marinha são competentes para mandar castigar corporalmente as praças da Armada, dentro dos limites de sua jurisdição; nunca porém excedendo o que marcam os regulamentos. O castigo corporal, que houver de ser de vinte e cinco chibatadas ou pranchadas de espada, e daí para cima, somente poderá ser feito vinte e quatro horas depois de cometido o delito, e a ele assistirá toda a guarnição do navio com os oficiais e comandante, devendo este por uma averiguação sumarissíma, feita perante a mesma guarnição antes de começar o castigo, mostrar a existência do delito que se trata de punir. ${ }^{23}$ 
Por outro lado, que os comandantes procuravam ocultar a vingança e as humilhações parece atestar a circular 76, de julho de 1864:

\begin{abstract}
Observando-se que, nos assentamentos das praças dos corpos de Marinha não vem exaradas as notas dos castigos sofridos por ela, quer proveniente dos crimes de $1^{\mathrm{a}}$ e $2^{\mathrm{a}}$ deserções, quer por outros, manda S. Ex. o Sr. ministro (...) da Marinha recomendar aos Srs. comandantes de forças e divisões navais, flotilhas e navios soltos, que façam lançar nos assentamentos dessas praças as notas dos castigos que por ventura elas sofram. ${ }^{24}$
\end{abstract}

Tratava-se, portanto, do sistema de suplícios, representado pela vingança do superior ofendido, que ocupava o lugar do Rei, isto é, do Estado. Assim, não representava, como se poderia supor, um desvirtuamento do Regimento Provisional e dos Artigos de Guerra, mas o coroamento lógico de todo o sistema do serviço militar.

Há ainda outra questão. A discussão feita pela seção de Guerra e Marinha em 1867 demonstra os primeiros sinais da crise que envolveu a Armada até o final do Segundo Reinado.

Antes de examinar a questão "principal ou de apreciar a reforma pedida sob o ponto de vista de sua conveniência", a seção de Guerra e Marinha apresentou duas questões preliminares - cuja discussão foi até agora adiada - que fornecem os elementos para se abordar a problemática ora apontada. As questões diziam respeito: 1) à natureza jurídica e política do requerimento; 2) à competência do poder executivo para deferir o pedido apresentado às autoridades.

No que diz respeito à natureza do documento, os conselheiros, argumentavam que não se tratava "de um simples requerimento [mas] verdadeiramente [de] uma petição coletiva, feita por várias praças de pré do corpo de imperiais marinheiros por si e como órgãos de seus camaradas ausentes(...)" (Consulta, p. 48). A Constituição do Império - afirmavam - garantia o direito de petição e esse direito podia e vinha sendo entendido em sentido amplo, mas, não excluindo petições coletivas, estava contudo sujeito a determinadas regras e condições para seu exercício legítimo.

24 Circular 76, de 20/07/1864. Ordens Gerais, 1864. 
Segundo a seção de Guerra e Marinha, "as opiniões eram concordes em que tais petições, a não serem de autoridades constituídas e sobre objeto de sua competência, deviam ser assinadas por todos e cada um dos peticionários (...)". A transposição desse princípio para o caso específico resultou na regulamentação do texto constitucional - que nada diz a respeito - através da interpretação dada pelos conselheiros à Carta Magna do Império:

...a nossa Constituição, dando igual direito a qualquer cidadão, e exigindo que ele seja feito por escrito, se não exclui as petições coletivas, também não as dispensa do requisito de serem revestidas das assinaturas de cada um dos indivíduos em cujo nome foram apresentadas, por que trata-se de um direito que por sua natureza não pode ser delegado (Consulta, p. 48).

Essa interpretação tinha por fundamento o pensamento de outro conselheiro, José Antonio Pimenta Bueno, que sustentava a doutrina da distinção em seu Direito Público Brasileiro e Análise da Constituição do Império, publicado em 1857. Segundo o jurista, o direito de petição era inteiramente distinto do de requerimento ou queixa, tendo outra natureza e outro fim:

É antes um direito político do que natural ou individual. É a faculdade legítima que o cidadão ativo tem de apresentar por escrito aos poderes públicos suas opiniões, suas idéias, interesses que partilha e seus votos sobre os negócios sociais de legislação ou de administração do Estado; é um direito quase semelhante ao da liberdade da imprensa política, uma espécie de intervenção no governo do país, não tanto em proveito seu particular, como no interesse geral (Consulta, $\mathrm{p}$. 48).

Era necessário, contudo, observar as regras e condições inerentes à sua natureza, para que não degenerasse em abuso, em perturbação da ordem e da paz públicas, ou comprimisse a liberdade de outros. A petição deveria ser feita por escrito respeitoso e também deveria ser assinada por todos e cada um, jamais poderia ser feita "sob nome ou denominação cole- 
tiva de sociedade política ou anônima, ou mesmo de municipalidade, pelo menos que não esteja para isso expressamente autorizada por lei"'(Consulta, p. 48).

Eis, portanto, um dos pontos centrais da questão: se o direito de petição era caracterizado como político, ele não poderia ser exercido coletivamente, a não ser que fosse permitido por lei ou aos mandatários por ela autorizados:

\begin{abstract}
É um direito pessoal que deve ser exercido pelo próprio cidadão, por isso mesmo que ele não pode delegar tais direitos senão aos mandatários que a lei autoriza, que não pode criar poderes além dos que esta criou. Consequentemente, nenhum corpo, administração, sociedade ou cidadão pode exercer este direito indelegável, nem constituir-se como entidade política em frente dos poderes legítimos (Consulta, p. 48).
\end{abstract}

Seguindo essa linha de pensamento, faltou muito pouco para a seção de Guerra e Marinha tentar enquadrar os signatários do requerimento no crime de sedição ou de rebelião. De fato, a Constituição exigia que o pedido fosse apresentado por escrito, mas não autorizava a distinção feita entre requerimento e petição. Ao contrário, no §30, do artigo 179, estabelecia o requerimento como forma legal e legítima de petição.

Não se vai muito longe, no entanto, acusando os conselheiros de, apoiados no pensamento de Pimenta Bueno, sofismar sobre o texto constitucional. A Constituição de fato foi, nesse ponto, interpretada e regulamentada, dando origem a uma jurisprudência. Tratava-se de uma operação para destituir de fundamento, de legitimidade e de legalidade o requerimento dos praças, ou seja, um meio para atingir um fim maior que a recusa dos direitos requeridos pelos praças.

A seção de Guerra e Marinha introduziu ainda uma outra distinção: não se estava diante de um fato comum, mas sim de um requerimento feito por militares, aos quais se aplicavam os princípios mencionados, mas não "com maior latitude, antes com algumas restrições" (Consulta, p. 48).

A primeira delas dizia respeito ao trâmite do requerimento. Ponderava a seção de Guerra e Marinha que os militares deveriam exercer o direi- 
to de requerimento, petição ou queixa por intermédio de seus chefes, ${ }^{25}$ para concluir:

\begin{abstract}
A presente petição do corpo de imperiais marinheiros não foi apresentada nos termos do aviso regulamentar de 1812, porque não seguiu restritamente a escala da hierarquia militar, subindo dos capitães das companhias para o comandante do corpo; e poderia percorrer estes trâmites, posto que endereçada ao trono, se não fosse o seu caráter coletivo. Também não se conforma ao princípio da constituição do Império, porque esta exige, como se observou, a assinatura de cada um dos peticionários, e a maior parte destes figuram aí por uma suposta delegação, ou ilegítima representação (Consulta, p. 49).
\end{abstract}

Eis, portanto, a interpretação de Pimenta Bueno - que não permite a delegação da representação a entidades associativas e, portanto, interdita a possibilidade de petições coletivas - transformada em princípio constitucional. Além disso, os conselheiros compreendiam que o caráter coletivo da petição impediu a obediência dos trâmites regulares, trazendo implícita, portanto, a idéia de quebra de hierarquia, fato não reconhecido como tal pelas autoridades militares, pelo conselho naval e pelo ministro da Marinha.

Os conselheiros afirmavam - repetindo o artigo 147 da Constituição Imperial - que a força militar é essencialmente obediente e, por conseqüência, não pode deliberar. Também consideravam válido para o Exército e a Armada o artigo 1 da Lei 602 de 1850, que estabelecia: "toda a deliberação tomada pela Guarda Nacional é um atentado contra a Liberdade, e um delito contra a Constituição." ${ }^{26}$ Deduziam os conselheiros, de toda essa teia legislativa, que "a petição coletiva pressupõe um exame, uma deliberação, e, pois, os corpos armados não têm o direito de petições coletivas" (Consulta, p. 49).

25 Os conselheiros recorreram aos termos do aviso de 3 de março de 1812 , que diz o seguinte: "Não se admitirá representação alguma que não seja feita na graduação de inferior para superior; excetuadas as queixas e gravames, que podem ser feitas ao superior imediato àquele contra quem se forma a queixa, devendo contudo o representante prevenir a este do objeto da representação". (Consulta, p. 49).

26 Lei 602 de 19/09/1850. Da nova organização à Guarda Nacional. CLI, 1850. 
Completa-se, pois, o caminho percorrido pela seção de Guerra e Marinha: definindo a natureza do pedido feito pelos praças como petição coletiva, reconhece esta como um direito político para então denegá-lo, em primeiro lugar, a todos os súditos do Império, pois a eles interdita a livre associação em sociedades políticas e anônimas, e, em segundo lugar e de modo especial, aos militares, sobre o pressuposto de que era ilegal, ilegítimo, inconstitucional e que representaria, portanto, uma quebra de hierarquia, um atentado à liberdade, um delito contra a Constituição, uma ameaça e uma perturbação da ordem. Um fato de "natureza especial e perigosa, cujo consentimento e acordo dos superiores militares dá maior alcance e reveste de toda sua gravidade" (Consulta, p. 57).

É possível, agora, verificar as conseqüências da interpretação dada à Constituição pelos conselheiros: se os praças obtiveram o acordo e consentimento dos superiores militares é porque, em nenhum momento, as autoridades - incluindo aí o ministro da Marinha - entenderam o requerimento como um atentado à Constituição e às demais leis vigentes no Império.

Pode-se, ao contrário, supor implícita ao menos uma autorização para a reunião e deliberação do Corpo de Imperiais Marinheiros com a finalidade de apresentar um requerimento (permitido aos militares) endereçado ao imperador e à Assembléia, por meio das autoridades competentes. A seção de Guerra e Marinha não poderia aceitar o fato e, por isso mesmo, denegava o direito dos cidadãos comuns e dos militares de endereçar ao imperador e à Assembléia quer um requerimento, quer uma petição - como visto, permitido pela Constituição e regulamentado pela legislação ordinária: o aviso regulamentar de 1812 e a ordem geral 65 de 1839, que ordenava o envio das representações e requerimentos ao quartel general da Armada. ${ }^{27}$

Assim, o endereçamento de um pedido na forma prescrita pela legislação não caracterizaria uma quebra da hierarquia e, menos ainda, uma violação da Magna Carta do Império. No entanto, se acolhido o pedido, estaria, na visão dos conselheiros, admitido um precedente que poderia em outras circunstâncias "gerar pretensões que acarretassem consigo alguma excitação lamentável" (Consulta, p. 49). Eis porque desce também sobre o ministro, o conselho naval e sobre os comandantes a censura pelo acata-

27 Ordem Geral 65 de 14/03/1839. Ordens Gerais, 1839. 
mento de fato tão perigoso, ato que representava tal perturbação da paz pública, tal ameaça à ordem.

Essa ameaça era sumamente grave, pois o requerimento - como a seção de Guerra e Marinha notou - atacava um ponto fundamental da lei do Corpo de Imperiais Marinheiros e o fez em "termos tão exagerados e desanimadores equiparando-se o tempo de serviço militar ao das penas dos maiores condenados" (Consulta, p. 49). Perguntavam-se os conselheiros: "Se os poderes competentes não anuírem à reforma pretendida, que bom efeito se pode esperar da lei atual, quando as praças de pré e os seus próprios superiores assim a têm apreciado e qualificado?" Tratava-se, portanto, de prevenir uma provável sedição pela recusa do direito e pela censura às autoridades da Marinha. Dizendo de outro modo, era necessário, na visão dos conselheiros, a interdição, a restrição, o constrangimento do direito para a manutenção da ordem social e política.

A segunda preliminar é bastante instrutiva nesse sentido. Nessa questão, a seção de Guerra e Marinha versava acerca da competência atribuída pelos comandos militares e pelo conselho naval ao poder executivo em deferir o requerimento dos praças. Segundo os conselheiros, se julgasse o governo imperial que a pretensão era digna de ser deferida, deveria encaminhá-la ao poder legislativo em relatório, ou proposta ou na forma que considerasse mais conveniente. Isso porque a legislação de 1854 "só autorizou a elevação do tempo de serviço dos imperiais marinheiros (salvos os direitos adquiridos) até o limite de vinte anos e que se lhes concedessem nesta hipótese certas e determinadas vantagens" e "direitos e deveres assim estabelecidos não [podiam] ser anulados ou modificados sem nova e prévia autorização do poder legislativo" (Consulta, p. 50). Assim, os conselheiros faziam uma outra censura aos oficiais superiores e ao conselho naval: não podiam pretender que suas aspirações fossem realizadas sem autorização do legislativo.

É fundamental ressaltar que, ao discutir a primeira questão, os conselheiros Nabuco e Paranhos qualificaram o requerimento dos praças como insubordinado e sedicioso. Fizeram, também, dos pareceres dos comandantes militares, do conselho naval e do próprio ministro da Marinha objeto de sua análise somente para censurá-los por terem consentido em um ato de tal gravidade e, mais ainda, por partilharem da mesma compreensão dos praças na equiparação do sistema militar às penas dos maiores condenados. Na discussão da segunda questão, o requerimento foi ignorado para 
que os conselheiros, criando a suposição de que os trâmites legais no encaminhamento da questão haviam sido desobedecidos, pudessem advertir, uma vez mais, as autoridades navais,

Os termos tão veementes que Nabuco e Paranhos empregaram revelam o temor frente às "excitações lamentáveis" que poderiam advir do acatamento dos termos do requerimento, ou seja, da rebelião - uma quebra na hierarquia social e política do país. A recusa dos termos do requerimento configurava, portanto, um recurso para a manutenção da ordem.

$\mathrm{O}$ fato ainda se revestia de particular gravidade naquele momento em que a guerra começava a provocar seus piores efeitos, com a paralização das operações militares e as divergências do comando aliado, com as críticas internas e externas à continuidade do conflito e ainda em meio às desavenças entre o cambaleante gabinete Zacarias e Caxias, que começavam a assumir maiores proporções. Em outras palavras, uma situação de profunda instabilidade da vida nacional, em que os mecanismos que asseguravam o monopólio da violência - o Exército, a Armada, a Guarda Nacional - estavam mobilizados para um conflito externo.

\section{Considerações finais}

A elaboração e o endereçamento do requerimento, bem como as reivindicações que portavam, foram, como visto, considerados de "natureza especial e perigosa", agravada pelo consentimento dos superiores militares, o que lhes dava maior alcance e os revestia em toda sua "gravidade". Como já visto, os militares, o conselho naval e o ministro da Marinha concordavam com a avaliação que os marinheiros faziam da lei. Esses aspectos da questão deixaram Nabuco e Paranhos alarmados também porque indicavam uma quebra do consenso nas redes de poder. Como poderia a lei ser cumprida e, mais ainda, como poderia ser preservado o sistema se os próprios encarregados por sua manutenção pareciam tomados por uma dúvida acerca de sua legitimidade?

Representava assim, não o requerimento em si, mas o consentimento em sua elaboração, a aceitação de seus termos pelas mais altas autoridades, uma rebelião silenciosa que se instalava nas próprias engrenagens 
do Estado, uma fratura em todo o seu edifício, e, por isso mesmo, a mais terrível ameaça, a mais difícil de ser combatida, pois, como observa Hannah Arendt,

\begin{abstract}
Onde os comandos não são mais obedecidos, os meios da violência são inúteis; e a questão desta obediência não é decidida pela relação de mando e obediência, mas pela opinião e, por certo, pelo número daqueles que a compartilham. Tudo depende do poder por trás da violência. A ruptura súbita e dramática do poder que anuncia as revoluções revela em um instante o quanto a obediência civil - às leis, aos dominantes, às instituições nada mais é do que a manifestação externa do apoio e do consentimento. $^{28}$
\end{abstract}

Certamente, os marinheiros não estavam pensando em promover nenhuma revolução, no entanto, os termos de suas reivindicações demonstravam o potencial revolucionário da consciência de direitos que revelavam possuir.

Por outro lado, um terceiro conselheiro, Antonio Paulino Limpo de Abreu, o visconde de Abaeté, refutou, através de voto em separado, os argumentos apresentados por Nabuco e Paranhos. Quanto à questão do documento, dizia: "A petição de que se trata está no caso de outras feitas coletivamente ao governo por oficiais e praças de corpos armados. Petições desta natureza tem sido aceitas pelo governo sem censura, nem objeção". Quanto ao direito de peticionar, observava: "Não há legislação expressa que negue à força armada o direito de petição, e ele tem sido efetivamente exercido(...). Entendo portanto, que o requerimento ou representação de que se trata, não deva ser repelido como será conseqüência lógica se por ventura prevalecer a doutrina sustentada pelo ilustre relator da seção" (Consulta, p. 56).

Segundo Abaeté, na Inglaterra existiam propostas no sentido de se reformar o sistema de recrutamento, bem como os castigos corporais no Exército haviam sido abolidos. Também "os homens profissionais, que tem escrito sobre o Exército e a Marinha da França, todos se inclinam à conveni- 
ência de reduzir o tempo de serviço e de melhorar a sorte do soldado e do marinheiro" (Consulta, p. 57).

Paulino articulava a questão à função do Exército e da Armada no conjunto do Estado e terminava por concluir que todo o sistema deveria ser alterado. Dizia ele da necessidade de uma força permanente, defensiva, na qual, o Exército e a Armada fossem "uma escola, pela qual os cidadãos passam, cada um por sua vez, para adquirirem suficiente hábito das armas e tornarem-se aptos para concorrer com o tributo, que se chama de sangue, nos dias de crise" (Consulta, p. 57).

Enfim, o visconde afirmava a compatibilidade de forças permanentes com a redução do tempo de serviço militar, procurando demonstrar que, nos países onde elas existiam, procurava-se "melhorar a sorte" de marinheiros e soldados e concluía que a legislação de 1854 deveria ser revista, tomando-se em consideração o requerimento apresentado, aguardando-se, no entanto, o final da guerra em curso.

Dessas apreciações de Abaeté fica a impressão, não somente de que petições e requerimentos eram comuns, bem como que ele, particularmente, não via como uma sedição, rebelião ou ameaça o conteúdo do requerimento apresentado. Por outro lado, as reflexões que fazia acerca das mudanças em curso nos exércitos e armadas europeus - sempre tomados como modelo pelos estadistas do Império - sugerem que elas não eram desconhecidas também de oficiais - sempre em viagens para aquele continente para realizar cursos ou acompanhamento de construções e compra de navios -, do conselho naval e nem do ministro da Marinha. Além disso, a própria natureza da constituição das guarnições da esquadra, com diversos regimes de tempo de serviço - os contratados serviam apenas por dois anos com prêmios e bonificações -, além da própria presença dos estrangeiros que, provavelmente partilhavam notícias de outros sistemas e realidades, tocou, provavelmente, no espírito daqueles marinheiros que decidiram tentar reivindicar aquilo que julgavam como sendo seus direitos e a ampliação de suas liberdades, em especial naqueles tempos de guerra.

Pode-se constatar, finalmente, que todos os envolvidos, praças, oficiais, ministro da Marinha e conselheiros sabiam, em 1867, que a Marinha, para não dizer as Forças Armadas, necessitava de urgentes e profundas reformas. Triunfou, no entanto, naquele momento, o parecer de Nabuco e de Paranhos, ou seja, a "moderação" da política imperial, aquela mesma 
que era quase como uma segunda natureza do imperador, no dizer de Sérgio Buarque, cujos poderes funcionaram "como catalisadores da resistência à qualquer mudança na estrutura tradicional, quando as mudanças implicavam mais do que uma estabilidade estéril e mentirosa" (HOLANDA, 1985, p. 20).

\section{Referências}

ARENDT, H. Sobre a violência. Rio de Janeiro: Relume-Dumará, 1994.

ARIAS NETO, J. M. Em busca da cidadania: praças da Armada Nacional, 18671910. São Paulo, 2001. Tese (Doutorado) - Universidade de São Paulo.

CALDEIRA, J. (Org.). Diogo Antônio Feijó. São Paulo: Editora 34, 1999.

CHALHOUB, S. Cidade febril. São Paulo: Cia. das Letras, 1996.

FOUCAULT, M. Vigiar e punir. 9. ed. Petrópolis: Vozes, 1987.

GREENHALGH, J. $O$ arsenal de marinha do Rio de Janeiro na História (18221889). Rio de Janeiro: Arsenal de Marinha, 1965.

HOLANDA, S. B. de. Do Império à República. In: HOLANDA, S. B. de (Dir.). História geral da civilização brasileira. 4. ed. São Paulo: Difel, 1985.

MARTINS, H. L. A revolta dos marinheiros: 1910. Rio de Janeiro: Serviço de Documentação Geral da Marinha, 1988.

NABUCO, J. Um estadista do Império. 5. ed. Rio de Janeiro: Topbooks, 1997.

RITCHIE, R. C. Capitão Kidd e a guerra contra os piratas. Rio de Janeiro: Campus, 1989.

RODRIGUES, J. Cultura marítima: marinheiros e escravos no tráfego negreiro para o Brasil (secs. XVIII e XIX). Revista Brasileira de História, São Paulo, v. 19, n. 38, p. 15-53, 1999.

SOUZA, O. T. de. História dos fundadores do Império do Brasil: Bernardo Pereira de Vasconcelos. São Paulo: Edusp, 1988.

TORAL, A. A. de. A participação dos escravos negros na Guerra do Paraguai. Estudos avançados, São Paulo, v. 9, n. 24, p. 287-298, maio/ago. 1995. 